\title{
Crustal STRUCTURE OF THE UlaANBAATAR REgion, MONGOLIA ACCORDING TO GRAVIMETRIC DATA
}

\author{
B. Buyantogtoh¹, E. Kh. Turutanov², V. S. Kanaikin³ \\ ${ }^{1}$ Institute of Astronomy and Geophysics of MAS, Ulaanbaatar, Mongolia \\ ${ }^{2}$ Institute of the Earth's Crust, Siberian Branch of RAS, Irkutsk, Russia \\ ${ }^{3}$ Irkutsk National Research Technical University, Irkutsk, Russia
}

\begin{abstract}
Establishing relationships between the regional seismicity and the depth geometry and compositions of large-size density inhomogeneities of the upper crust is one of the ways to determine the parameters of mean longterm seismicity. The origin of geological bodies and mechanisms of penetration of intrusive bodies into the upper crust are detectable from the shapes and sizes of such bodies. Knowledge on the shapes and sizes of large intrusive bodies is important for prospecting and exploration of mineral resources. Based on the medium-scale areal gravimetric survey data, a regional map of Bouguer gravity anomalies was constructed for the Ulaanbaatar region, Central Mongolia. Interpreted gravimetric data from the solutions of the inverse problem of gravimetry based on the bodyshape selection were used to develop the 3D models showing the largest crustal density inhomogeneities of the study area - the Tolskaya (Ulaanbaatar) basin, Nalaiha depression and Bogdoulin granite massif. It is confirmed that the basement of these depressions has a block structure. The basement of the Tolskaya basin includes two depressions, the western and eastern ones. In the western depression, the sediment thickness is $150 \mathrm{~m}$. It amounts to $400 \mathrm{~m}$ in the eastern depression at the intersection of the Selbin and Tolskaya deep fault systems. The information on the shapes and thicknesses of the sediment bodies is used in the seismic studies aimed at obtaining a more precise assessment of seismic hazard of the Ulaanbaatar city and the region. In the Nalaiha depression, the sediments are $800 \mathrm{~m}$ thick. The morphology of the basement and the thickness of sediments in this depression can be used to update the mining prospects of the Nalaiha coal deposit. The maximum thickness of granitoids in the Bogdoulin massif is $9.0 \mathrm{~km}$. The area of its projection to the ground surface is twice as big as the area of the outcrops. Our research results can be useful for assessing the metallogenic specialization of granitoids, which indicators in relation to some minerals are related to the specific features of the Bogdoulinsky massif. Such indicators have been discovered by the geological, geophysical and geochemical methods. Our study shows that the geophysical methods (in particular, gravimetry) can considerably expand the knowledge of the morphology of geological objects at depth and facilitate reaching a new level in structural analysis, which is critical for developing new ideas to clarify the geological history and tectonic conditions of the formation of the Mongolia-Siberian region.
\end{abstract}

Key words: gravity anomaly; shape and size; sedimentary deposits; granite massif

Статья публикуется по материалам доклада, сделанного авторами на XII Российско-Монгольской международной конференции «Солнечно-земные связи и геодинамика Байкало-Монгольского региона» (1-5 октября 2018 г., г. Иркутск)

RESEARCH ARTICLE

Received: October 24, 2018

Revised: March 26, 2019

Accepted: April 3, 2019

For citation: Buyantogtoh B., Turutanov E.Kh., Kanaikin V.S., 2019. Crustal structure of the Ulaanbaatar region, Mongolia according to gravimetric data. Geodynamics \& Tectonophysics 10 (3), 585-602. doi:10.5800/GT-2019-10-3-0428. 


\title{
СТРУКТУРА ЗЕМНОЙ КОРЫ УЛАН-БАТОРСКОГО РАЙОНА МОНГОЛИИ ПО ГРАВИМЕТРИЧЕСКИМ ДАННЫМ
}

\author{
Б. Буянтогтох ${ }^{1}$, Е. X. Турутанов ${ }^{2}$, В. С. Канайкин ${ }^{3}$ \\ ${ }^{1}$ Институт астрономии и геофизики МАН, Улан-Батор, Монголия \\ ${ }^{2}$ Институт земной коры СО РАН, Иркутск, Россия \\ ${ }^{3}$ Иркутский национальный исследовательский технический университет, Иркутск, Россия
}

\begin{abstract}
Аннотация: Одним из способов оценки параметров долговременной средней сейсмичности является установление связи последней с глубинной геометрией и составом крупных плотностных неоднородностей верхней части земной коры. Кроме того, сведения о форме и размерах геологических тел дополняют информацию о их образовании и механизме проникновения (для интрузивных тел) в верхние части земной коры. Не менее важны знания о форме и размерах крупных интрузивных тел для поисков и разведки полезных ископаемых. По результатам площадной гравиметрической съемки среднего масштаба, выполненной на территории Улан-Баторского района (Центральная Монголия), построена карта аномалий силы тяжести в редукции Буге. На основе интерпретации полученных гравиметрических данных (решение обратной задачи гравиметрии методом подбора формы тел) определены 3D-модели крупнейших плотностных неоднородностей земной коры района - Улан-Баторской (Тольской) впадины, Налайхинской котловины и Богдоулинского гранитного массива. Установлено, что фундамент депрессий имеет блоковое строение. В Тольской впадине он осложнен двумя котловинами - западной и восточной. Мощность осадочных отложений в западной котловине составляет 150 м, в восточной котловине (в районе пересечения Сэльбинской и Тольской систем глубинных разломов) может достигать 400 м. Сведения о форме и размерах осадочных отложений будут использованы при инженерно-сейсмологических работах по уточнению сейсмической опасности города Улан-Батора. Мощность осадочных отложений в Налайхинской котловине достигает 800 м. Данные о морфологии фундамента и мощности осадков во впадине могут быть использованы для уточнения перспектив эксплуатации Налайхинского угольного месторождения. Максимальная толщина гранитоидов Богдоулинского массива составляет 9.0 км, площадь его проекции на земную поверхность в два раза превосходит площадь выходов. Результаты исследований могут быть полезными для оценки металлогенической специализации гранитоидов, признаки которой в отношении отдельных минералов связаны с особенностями формы Богдоулинского массива и установлены геолого-геофизическими и геохимическими исследованиями. Как показали выполненные исследования, геофизические методы (в частности, гравиметрический), значительно расширяя наши знания о морфологии геологических объектов на глубине, помогают достичь нового уровня в структурном анализе, без которого невозможно разработать полноценные представления об истории развития и тектонических условиях формирования Монголо-Сибирского региона.
\end{abstract}

Ключевые слова: аномалия силы тяжести; форма и размеры; осадочные отложения; гранитный массив

\section{1. ВВЕДЕНИЕ}

Сейсмическая активность Монголо-Сибирского региона, по-видимому, связана с геодинамическими процессами, например рифтогенезом, которые, в свою очередь, неравномерно проявляются в пространстве. Причиной этого может быть как различие в интенсивности глубинных процессов, так и различие участков литосферы по механическим свойствам [Turutanov, 2012a].

Действительно, сопоставление морфологических особенностей кайнозойских осадков впадин Байкальской горной области с неоднородностями фундамента показывает, что впадины тяготеют преимущественно к контактам гранитов с метаморфическими породами [Turutanov, 2010]. Котловины локализуются чаще всего на гранитном субстрате, при этом сама зона контакта превращается в одну из границ впадины. По-видимому, граниты являются менее прочными образованиями, чем глубокометаморфизованные породы древнего фундамента, а внедрение интрузий нарушает первоначальную однородность коры и снижает ее механическую прочность по сравнению с участками, где граниты на глубине отсутствуют. Поскольку геологические объекты характеризуются в основном вещественным составом и геометрическими особенностями слагающих их литологических комплексов, одной из возможных причин повышения сейсмической активности, по-видимому, является ее связь с указанными параметрами физико-геологической среды. Иными словами, есть все основания предполагать, что одним из способов оценки долговременной средней сейсмичности является установление связи последней с глубинной геометрией и составом крупных плотностных неодно- 
родностей верхней части земной коры. Кроме того, сведения о форме и размерах геологических тел дополняют информацию о их образовании и механизме проникновения (для интрузивных тел) в верхние части земной коры.

Не менее важны знания о форме и размерах интрузивных тел для поисков и разведки полезных ископаемых. С кислыми послескладчатыми гранитами генетически и пространственно связана подавляющая часть месторождений и рудопроявления вольфрама, олова и других редких металлов Монголо-Сибирского региона. Здесь месторождения первых двух элементов локализуются преимущественно в экзоконтактовых зонах над кровлей мезозойских гранитных массивов, выступы которой, не вскрытые денудацией, вполне уверенно выделяются по локальным (остаточным) гравитационным аномалиям высокого порядка [Turutanov, 2010, 2012b]. Другие редкие металлы образуют промышленные скопления в эндоконтактовых зонах апикальных частей интрузивов. Такое распределение минерализации вызывает интерес к морфологии гранитных плутонов. При этом могут быть получены важные сведения для ориентировки поисковых работ в районах, где рудоносные граниты слабо вскрыты на уровне современного денудационного среза.

Улан-Баторская (Тольская) и Налайхинская впадины, а также Богдоулинский гранитный массив являются наиболее крупными плотностными неоднородностями верхней части земной коры района исследований, находятся в зоне высокой сейсмической активности и могут оказать заметное влияние на уровень сейсмичности. Кроме того, Налайхинская котловина обладает промышленным запасом бурых углей, а недра Богдоулинского массива богаты многочисленными рудопроявлениями редких и цветных металлов. Следовательно, глубинное строение Улан-Баторской и Налайхинской впадин, равно как и перспективный на широкий спектр металлических полезных ископаемых Богдоулинский гранитный массив, вызывает закономерный научно-практический интерес.

Если глубокие недра Хэнтэйской зоны Монголии в геофизическом отношении изучены достаточно полно [Zorin et al., 1989, 1994], то сведений о структуре самых верхних горизонтов земной коры этого региона явно недостаточно. В связи с этим изучение формы и размеров перечисленных объектов представляет актуальную задачу.

Морфология крупных геологических неоднородностей земной коры, как показали геофизические исследования Монголо-Сибирского региона, достаточно надежно устанавливается с помощью инверсии потенциальных полей, в частности гравиметрического [Turutanov, 2010, 2011, 2012b].

\section{2. ОСНОВНЫЕ ЧЕРТЫ ГЕОЛОГИЧЕСКОГО СТРОЕНИЯ РАЙОНА}

Фундамент района (рис. 1) представлен породами верхнего рифея - нижнего кембрия, характеризующими нижнепалеозойский структурно-формационный этаж, состоящий главным образом из осадочно-метаморфических пород (различные сланцы, гравелиты, песчаники с прослоями яшм и туффитов).

Среднепалеозойские отложения в районе исследований представлены комплексом незакономерно чередующихся вулканомиктовых, полимиктовых, реже граувакковых песчаников, алевритопесчаников, аргиллитов. Среди терригенных пород преобладают массивные неслоистые разности. Девонская толща Улан-Баторского района постепенно сменяется флишоидными отложениями нижнего карбона и остатками флоры и брахиопод. Мощность девона здесь 2500-3000 м. Среднепалеозойские отложения собраны в складки антиклинального типа в основном северо-восточного простирания. Породы падают на северо-запад под углом 50-70.

Каменноугольные отложения пользуются исключительно широким распространением в районе исследований и являются одними из главных элементов стратиграфического разреза. Они имеют морское происхождение, представлены в основном песчаниками и алевролитами и нередко характеризуются флишоидным строением. В их низах иногда встречаются яшмоиды, туфогенные породы и эффузивы среднего состава. Разрезы нижней толщи изучены по обоим склонам долины р. Улиастайн-гол, в долине р. Тола севернее сомона Налайх и южнее сомона Алтан-Обо, а также на северном склоне гранитоидного массива Богдоул. Наиболее низкие горизонты, вероятно, вскрыты лишь по р. Тола севернее сомона Налайх и на северных склонах массива Богдоул. Они представлены темными кремнисто-глинистыми алевролитами и мелкозернистыми песчаниками, ритмично (150200 м) чередующимися с мощными пачками яшм и туффитов. Вверх по разрезу переслаивание становится более частым, причем возрастает роль мелко- и среднезернистых песчаников. В верхней части разреза нижней толщи присутствуют прослои (до 5 м) яшм, туфов, изредка известняков. Самые верхние толщи, представляющие переслаивание песчаников и алевролитов, обнажены на северной окраине Улан-Батора. Видимая мощность нижней толщи в районе Улан-Батора колеблется от 400 до 1400 м. К востоку, в окрестностях Улан-Батора и в междуречье Толы и Тэрэлжийн, мощность верхней толщи составляет 1200-1500 м [Marinov et al., 1973].

Меловые отложения (нижний отдел) пользуются широким распространением на территории района. 


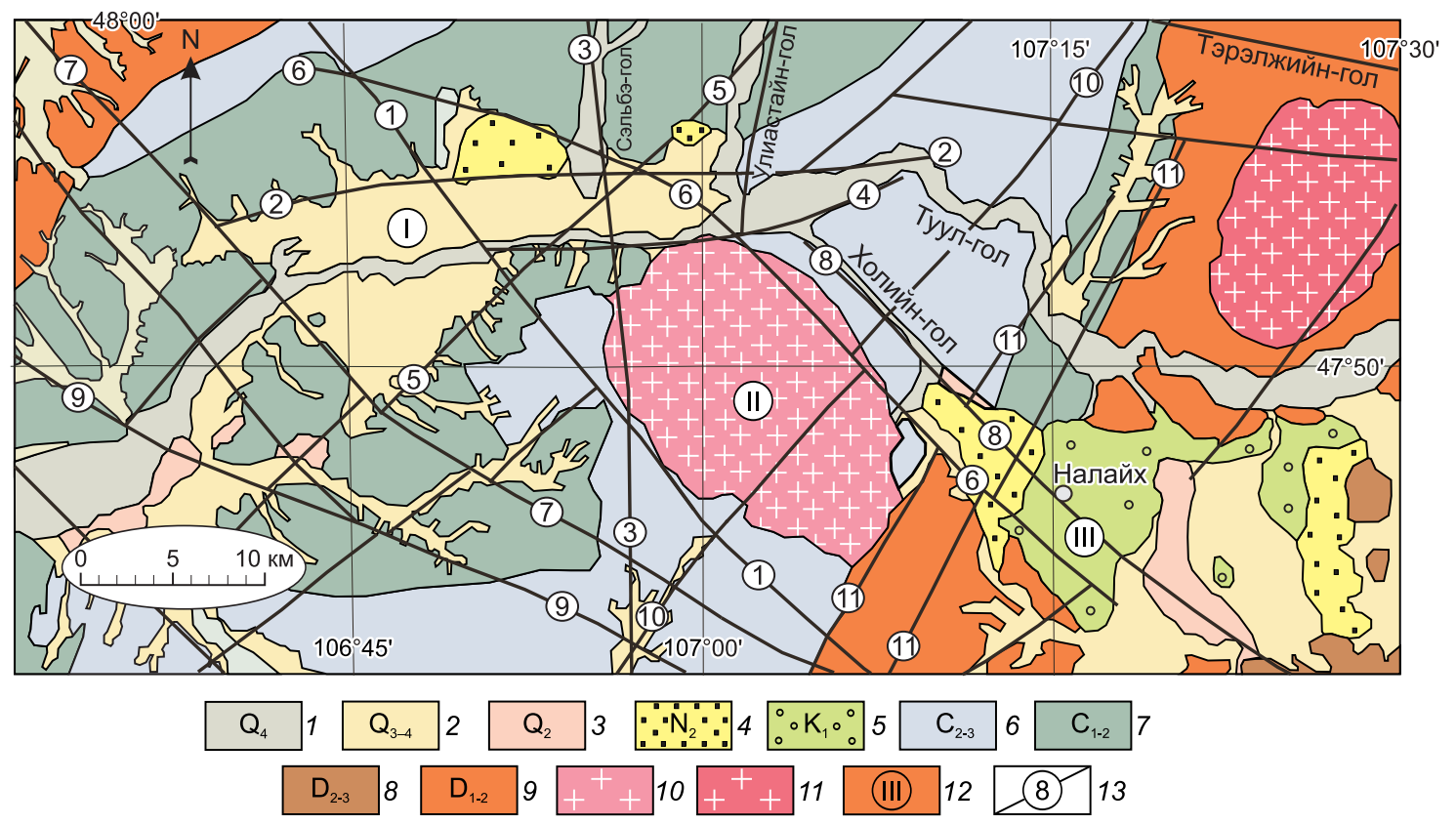

Рис. 1. Геологическая схема района исследований (по [Marinov et al., 1973; Bat, 2004; Dzhurik et al., 2009], с изменениями).

1-3 - четвертичные отложения: 1 - аллювиальные отложения: галька, гравий, песок, супесь, суглинок, глины; 2 - аллювиальнопролювиальные отложения: глыбы, дресва, щебень, галька с суглинисто-супесчаным заполнением, делювиально-пролювиальные отложения; 3 - отложения древних низких речных террас: глыбы, дресва, щебень, галька с суглинисто-супесчаным заполнением, супесь, суглинок; 4 - верхненеогеновые-плиоценовые отложения: красноцветные, иногда желтовато-пестрые глины, алевритовые гальки, пески, слабоцементированные брекчии, конгломераты, гравелиты, суглинки; 5 - нижний мел: песчаники с фауной и флорой, алевролиты, конгломераты, гравелиты, глины, аргиллиты; 6 - средний - верхний карбон: разнозернистые песчаники с прослойками глинистых сланцев, редко гравелиты, конгломераты, алевролиты; 7 - нижний - средний карбон: глинистые сланцы с прослойками разнозернистых песчаников, алевролиты, кремнистые алевролиты, редко прослойки яшм; 8 средний - верхний девон: желтоватые средне- и мелкозернистые песчаники, туфопесчаники, редко линзы яшм, прослойки туффитов; 9 - нижний - средний девон, нижний горизонт: песчаники с чередующимися прослойками алевролитов и сланцев, алевритопесчаный кварцит, редкие линзы основных эффузивов; 10 - средне и позднеюрский Богдоулинский гранитный массив, харалгайская формация: гранит-порфиры с биотитом и мусковитом, мелко- и среднезернистые граниты с биотитом и мусковитом, редко с аляскитом, средне- и крупнозернистые порфировидные граниты с биотитом, аляскитом, иногда щелочные; 11 позднетриасовый - раннеюрский Горихинский гранитный массив, жанчивланская формация: мелкозернистые гранитпорфиры, кварцевые жилы, среднезернистые граниты, среднезернистые порфировидные светлые граниты с биотитом, роговой обманкой, средне- и крупнозернистые порфировидные граниты с биотитом, биотитовой и роговой обманкой, мусковитом; 12 цифры (римские) в кружках - крупнейшие плотностные неоднородности верхней части земной коры Улан-Баторского района: I - Улан-Баторская (Тольская) впадина, II - Богдоулинский гранитный массив, III - Налайхинская котловина; 13 - крупные разломы, установленные по геологическим данным. Цифры (арабские) в кружках - названия разломов (по [Dzhurik et al., 2009]): 1 Шижирбогдоулинский, 2 - Северо-Тольский, 3 - Сэльбинский, 4 - Южно-Тольский, 5 - Гацууртынский, 6 - Баянхошуунский, 7 Сонгиноульский, 8 - Хонхоринский, 9 - Тургэнийский, 10 - Хундайский, 11 - Дэндэйская система разломов.

Fig. 1. Schematic geological map of the study area (modified after [Marinov et al., 1973; Bat, 2004; Dzhurik et al., 2009].

1-3 - Quaternary sediments: 1 - alluvial deposits: pebbles, gravel, sand, sandy loam, loam, clay; 2 - alluvial-proluvial deposits: blocks, gravel, rubble, pebbles with loamy-sandy filling, deluvial-proluvial deposits; 3 - deposits of ancient low river terraces: blocks, gravel, rubble, pebbles with loamy-sandy filling, sandy loam, loam; 4 - upper Neogene-Pliocene deposits: red-coloured, rare yellowish clay, aleuritic pebbles, sand, weak-cemented breccias, conglomerates, gravelites, loam; 5 - lower Cretacious deposits: sandstones with fossils, siltstones (aleurolites), conglomerates, gravelites, clays, mudstones (argillites); 6 - middle-upper Carbon: sandstones of different grain sizes with shale interlayers, rare gravelites, conglomerates, siltstones; 7 - lower-middle Carbon: shale interlayed with sandstones of different grain sizes, siltstone, siliceous siltstone, rare jasper interlayers; 8 - middle-upper Devonian: yellowish medium- and fine-grained sandstones, tuff sandstones, rare jasper lenses, tuffite interlayers; 9 - lower-medium Devon, lower horizon: sandstones with alternating layers of siltstone and shale, sandy silt quartzite, rare lenses of basic effusives; 10 - middle and Late Jurassic Bogdoulinsky granite massif, Kharalgai formation: granite-porphyry with biotite and muscovite, fine- and medium-grained granites with biotite and muscovite, rarely with alaskite, medium-coarse-grained porphyric granites with biotite, alaskite, rare acidic; 11 - Late Triassic - Early Jurassic Gorikhinsky granite massif, Zhanchivlan formation: fine-grained granite porphyry, quartz veins, medium-grained granites, medium-grained porphyritic lightcoloured granites with biotite, hornblende, medium- and coarse-grained porphyritic granites with biotite, biotite and hornblende, muscovite; 12 - Roman numbers in circles - the largest density inhomogeneities of the upper crust of the Ulaanbaatar region: I - Ulaanbaatar (Tolskaya) basin, II - Bogdoulin granite massif, III - Nalaiha depression; 13 - large faults confirmed by the geological data. Arabic numbers in circles - fault names (after [Dzhurik et al., 2009]): 1 - Shizhirbogdoulin, 2 - North Tolsky, 3 - Selbin, 4 - South Tolsky, 5 - Gatsuurtyn, 6 - Bayanhoshouun, 7 - Songinoul, 8 - Honhorin, 9 - Turgeni, 10 - Hundai, 11 - Dendei fault system. 
Состав их весьма разнообразен. Широко развиты песчаники, алевролиты, аргиллиты, глинистые и углистые сланцы и известняки, глины, угли. В многочисленных крупных грабенах и небольших котловинах юго-восточного склона Хэнтэя они представлены преимущественно эффузивами основного и среднего состава (реже кислого). Угли имеют черную или бурую окраску, остальные породы - пеструю. Мощность отложений достигает 500 м.

Кайнозойский структурно-формационный этаж представлен неогеновой красноцветной терригенной формацией континентального типа и терригенной формацией континентального типа четвертичного периода.

Неогеновые отложения слагают небольшие поля в долине р. Тола, на юго-западе г. Улан-Батора, на площади Налайхинской впадины и во впадине, расположенной восточнее ее. Верхняя часть разреза Улан-Баторской (Тольской) впадины представлена глинистыми толщами неогена, перекрытыми грубозернистыми аллювиальными, аллювиально-пролювиальными и делювиально-пролювиальными четвертичными отложениями. К северному борту УланБаторской (Тольской) впадины приурочены верхненеогеновые-плиоценовые отложения, представленные красноцветными, иногда желтовато-пестрыми глинами, алевритовой галькой, песками, слабоцементированными брекчиями, конгломератами, гравелитами и суглинками. Наиболее крупные выходы этих образований отмечены между выходом палеозойских гранитов и правым берегом р. Сэльбэгол (рис. 1), в районе пересечения крупных разломов - Гацууртынского и Баянхошуунского. Мощность их достигает 350-400 м [Marinov et al., 1973].

Четвертичные отложения пользуются повсеместным распространением на территории УланБаторского района. По генезису среди них выделяются коллювиальные, делювиально-дефлюкционные, делювиально-солифлюкционные, элювиальные, ледниковые и вулканогенные образования. Мощность аллювиальных отложений в долине p. Тола в районе г. Улан-Батора достигает 30 м. По данным инженерно-геологических исследований [Medvedev, 1971], участок долины реки Тола, расположенный в пределах Улан-Баторской (Тольской) депрессии, в основном сложен аллювиальными отложениями, состоящими из гальки, гравия, песка, супеси, суглинка и глины. В основном же осадочные образования самой впадины выполнены аллювиально-пролювиальными отложениями, включающими глыбы, щебень, гальку с суглинисто-супесчаным заполнением, и делювиально-пролювиальными отложениями [Bat, 2004].

В 35 км к юго-востоку от Улан-Баторской (Тольской) депрессии расположена Налайхинская впадина мезозойского заложения. Она имеет субширот- ную ориентировку и заполнена нижнемеловыми отложениями, залегающими с угловым несогласием на терригенных образованиях Хэнтэйской серии (рис. 1). Вмещающие ее среднепалеозойские отложения собраны в крутые изоклинальные складки преимущественно северо-восточного простирания. К депрессии приурочено Налайхинское месторождение бурых углей [Dugaraa, Arvysbaatar, 1982].

\section{3. ГРАВИМЕТРИЧЕСКАЯ СЪЕМКА И АНОМАЛИИ СИЛЫ ТЯЖЕСТИ}

Гравиметрическая съемка выполнена с помощью гравиметров scintrex autograv CG-5 по стандартной методике. Высота пунктов наблюдения определялась приборами Trimble 5700 GPS. Среднеквадратическая точность вычисления гравитационных аномалий в редукции Буге и густота сети наблюдений отвечают техническим требованиям, предъявляемым к гравиметрическим съемкам масштаба 1:100000. Поправка за рельеф введена в радиусе 200 км. По результатам гравиметрической съемки на территории района исследований выделена цепочка из трех гравитационных минимумов силы тяжести, вытянутая в северо-западном направлении (рис. 2) в соответствии с простиранием крупных региональных разломов - Шижирбогдоулинского, Сэльбинского, Баянхошуунского и Хонхоринского (см. рис. 1). На северо-западе района работ минимумы силы тяжести приурочены к площади УланБаторской (Тольской) впадины. В западной и центральной части впадины они имеют разную интенсивность. Амплитуда западного минимума составляет ориентировочно около 4 мГал, а центрального - почти вдвое больше (рис. 2). Центральную часть Улан-Баторского района занимает наиболее крупноамплитудный минимум силы тяжести. Этот экстремум полностью совпадает с выходами гранитоидов Богдоулинского массива и целиком ими обусловлен. На юго-востоке, в 20 км от богдоулинских гранитоидов, наблюдается интенсивный минимум силы тяжести, связанный с осадочными (Зуунбаянская свита мелового возраста) отложениями Налайхинской котловины.

\section{4. РЕЗУЛЬТАТЫ ИНТЕРПРЕТАЦИИ ГРАВИТАЦИОННЫХ АНОМАЛИЙ}

\section{1. УЛАН-БАТОРСКАЯ (ТОЛЬСКАЯ) ВПАДИНА}

Впадина расположена в пределах Хэнтэйского прогиба, слагающего центральную часть Хэнтэйского свода Монголо-Забайкальской (Хангай-Хэнтэйской) складчатой системы Монголии, между 


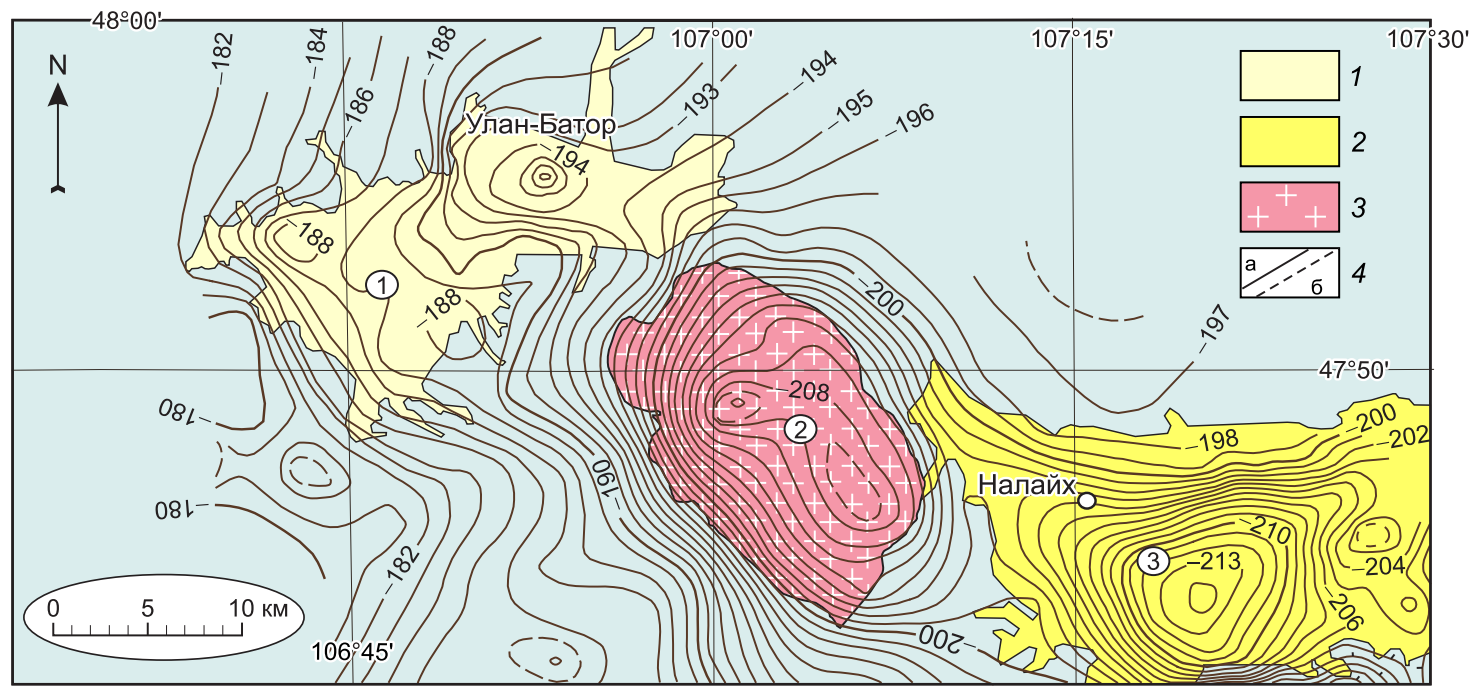

Рис. 2. Схема гравитационных аномалий района исследований в редукции Буге. 1 - Улан-Баторская (Тольская) впадина; 2 - Богдоулинский гранитный массив; 3 - Налайхинская впадина; 4 - изоаномалы силы тяжести, мГал: а - основные, б - дополнительные.

Fig. 2. Schematic map of the study area showing Bouguer gravity anomalies. 1 - Ulaanbaatar (Tolskaya) basin; 2 - Bogdoulin granite massif; 3 - Nalaikha depression; 4 - gravity isoanomals, mGal: a - main, 6 - additional.

малым Хэнтэйским поднятием и горстовой блоковой структурой гранитоидов массива Богдоул [Marinov et al., 1973; Yanshin, 1975]. Она имеет субширотную ориентировку (в крест простирания пород докайнозойского фундамента) и находится в пределах Тольской системы грабенов и горстов, которую пересекает в северо-восточном направлении Тольский разлом (Тольская система разломов) [Dzhurik et al., 2009]. Размеры впадины составляют (30-35)×(4-10) км. Площадь работ в Тольской впадине составила 574 км² $^{2}$ Всего выставлено 1143 координатных пункта. Точность гравиметрических наблюдений составила \pm 0.04 мГал, погрешность вычисления высот составила \pm 0.22 м. Кайнозойские отложения являются наименее плотными из всех геологических образований региона. Так как дополнительные сведения о их мощности почти отсутствуют, единственным критерием выделения локальных гравитационных минимумов, связанных с линзами этих отложений, является приуроченность указанных аномалий к площади впадины. Такая приуроченность характерна для Улан-Баторской (Тольской) впадины, что подтверждают многочисленные буровые данные, полученные в долине реки Тола [Bat-Elziy, Dorzh, 1988]. Средняя плотность рыхлых отложений принята по данным результатов многочисленных денситометрических измерений [Vakhromeev, 1979; Dzhurik et al., 2009] и составляет 2120 кг/м³. Вмещающие впадину породы представлены в основном нижнекарбоновыми песчаниками, сланцами и алевролитами. Величина плотности коренных пород, с учетом подстилаю- щих их гранитоидов, принимается по [Didenko et al., 1994; Dugaraa, Arvysbaatar, 1982; Nagibina, 1963; Dzhurik et al., 2009] и в среднем равна 2630 кг/м ${ }^{3}$. Наблюдаемая заливообразная аномалия силы тяжести в редукции Буге в западной части впадины (рис. 2) располагается на площади сплошного развития речных отложений, и ее можно рассматривать как проявление увеличения мощности осадочных образований. В центральной части УланБаторской впадины фиксируется сравнительно крупный гравитационный минимум, экстремальная часть которого совпадает с выходами глин и галечников верхненеогеновых - плиоценовых отложений Улан-Баторской впадины (см. рис. 1 и 2). Эта аномалия силы тяжести изометричной формы в центральной части впадины может быть связана с линзами неогеновых и четвертичных отложений.

Количественное выделение локальных (остаточных) аномалий Улан-Баторской впадины выполнялось по профилям в предположении о линейном изменении регионального фона. Линии регионального фона проводились как касательные к максимумам, окружающим депрессию, либо к участкам выполаживания графиков аномалий Буге [Turutanov, 2012b]. Схема локальных аномалий Улан-Баторской впадины построена по семи интерпретационным профилям (рис. 3), шесть из которых расположены в крест простирания впадины, один профиль (связующий) проходит вдоль впадины. Геологическое тело моделировалось ограниченными по простиранию горизонтальными призмами, поперечные сечения которых описываются 


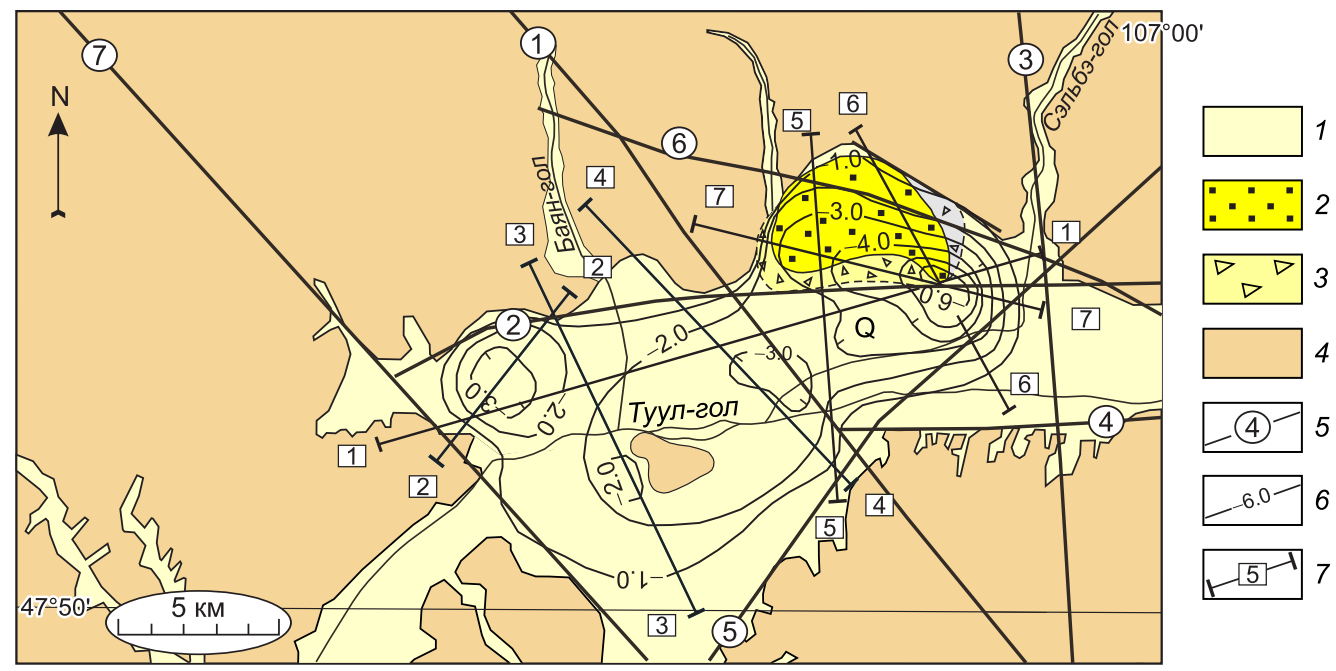

Рис. 3. Схема локальных (остаточных) гравитационных аномалий Улан-Баторской (Тольской) впадины (в относительном уровне, сечение изоаномал через 1 мГал). 1-5 - см. усл. на рис. $1 ; 6$ - изолинии локальных аномалий силы тяжести, мГал; 7 - интерпретационные профили. Цифры в квадратах - номера интерпретационных профилей.

Fig. 3. Schematic map of the Ulaanbaatar (Tolskaya) basin showing local (residual) gravity anomalies (relative level; cross sections of isoanomals every $1 \mathrm{mGal}$ ). 1-5 - see Fig. 1 for the legend; 6 - local gravity isoanomals, mGal; 7 - interpretation profiles. Numbers in squares - numbers of interpretation profiles.

многоугольниками [Godson, 1983; Webring, 1985]. Путем минимизации суммы квадратов отклонений вычисленной аномалии от наблюдаемой подбирались либо координаты вершин многоугольников, либо аномальные плотности, исходя из некоторого начального приближения этих параметров. В качестве ограничений на результаты инверсии гравитационных аномалий использовались геологические данные. Все профили взаимно увязаны между собой (в точках их пересечений интенсивность регионального фона имеет одинаковую величину, вследствие чего при интерпретации величина мощности осадков на этих участках оказывается также одинаковой). Зоны градиентов изопахит предположительно интерпретировались как разломы. Результаты интерпретации гравитационных аномалий, наблюдаемых в районе Улан-Баторской (Тольской) впадины отражены на интерпретационных разрезах (рис. 4) и составленной на их основе структурной схеме депрессии (рис. 5).

Судя по интерпретационным разрезам и схеме мощности осадочных отложений (см. рис. 4 и 5), Улан-Баторская (Тольская) впадина имеет сложное блоковое строение и по своей внутренней структуре разделяется на две неравные части - западную и восточную котловины. Длинные оси котловин расположены под углом $90^{\circ}$ друг к другу и вытянуты в направлениях, совпадающих с простиранием разрывных нарушений, ограничивающих впадину с юго-запада, юга и северо-востока (см. рис. 1). Западная часть Улан-Баторской (Тольской) депрессии в своем юго-западном окончании ограничена зоной тектонических нарушений, установленных по геологическим данным. Здесь на основе гравиметрических исследований выявлена котловина в форме овала с размерами $4.0 \times 3.5$ км. Мощность осадков в ней, судя по расчетам, составляет около 150 м (см. рис. 4 и 5). Бо́льшая ось ее ориентирована в северо-западном направлении вдоль западного борта впадины - в крест простирания Улан-Баторской (Тольской) депрессии (согласно основному направлению простирания пород докайнозойского фундамента) и контролируется Сонгиноульской разломной структурой той же ориентировки. Можно полагать, что западный борт этой котловины является западным ограничением самой УланБаторской (Тольской) впадины. Восточная часть Улан-Баторской (Тольской) впадины представляет собой вытянутую в северо-восточном направлении сложнопостроенную асимметричную структуру, состоящую из двух неодинаковых по размерам и мощности осадков мульдообразных прогибов фундамента (котловин) (см. рис. 4 и 5). Мощность осадочных отложений этой котловины убывает в направлении с северо-востока на юго-запад (в сторону выхода фундамента). Северо-восточное окончание этой структуры (Сэльбинская котловина), эпицентральная часть которой расположена в устье р. Сэльбэ-гол, является самым крупным структурным элементом не только восточной части, но и Тольской впадины в целом. Она имеет форму овала с размерами $10 \times 5$ км, ее длинная ось направлена в северо-западном направлении и совпадает с ориентировкой Баянхошуунского регио- 


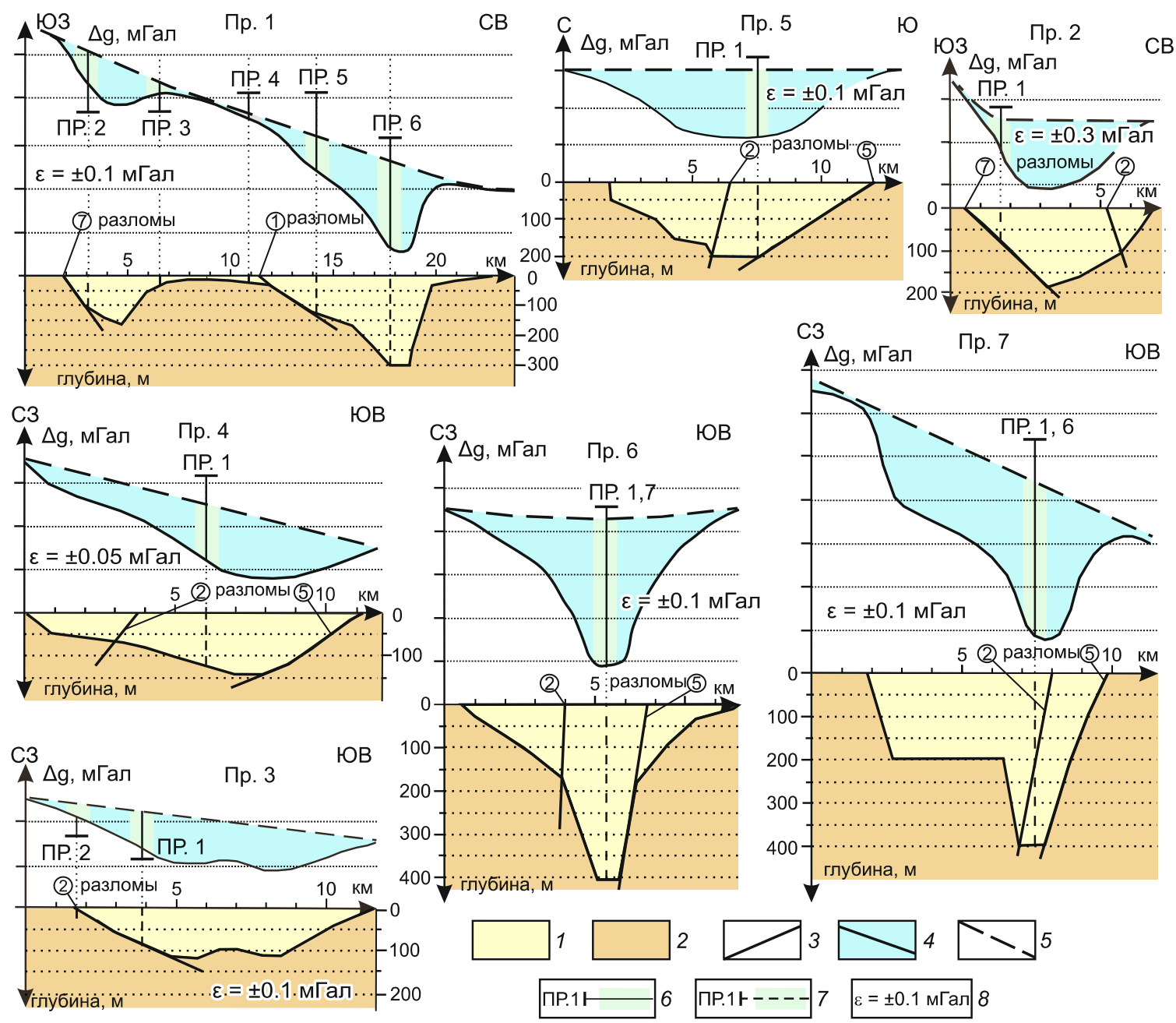

Рис. 4. Интерпретационные разрезы Улан-Баторской (Тольской) впадины.

1 - осадочные отложения; 2 - вмещающие породы; 3 - крупные разломы, установленные по геологическим данным (цифры в кружках - названия разломов (на рис. 1); 4 - графики аномалий силы тяжести в редукции Буге; 5 - графики регионального фона; 6 - точки пересечения и значения величины регионального фона в местах пересечения интерпретационных профилей; 7 - точки пересечения и значения мощности (толщины) гранитоидов в местах пересечения интерпретационных профилей. Положение профилей см. на рис. 3; 8 - среднеквадратические погрешности подбора моделей на интерпретационных профилях.

Fig. 4. Interpretation profiles of the Ulaanbaatar (Tolskaya) basin.

1 - sediments; 2 - host rocks; 3 - large faults confirmed by the geological data (numbers in circles - fault names (see Fig. 1); 4 - curves of Bouguer gravity anomalies; 5 - regional background gravity curves; 6 - intersection points and values of the regional background gravity at the intersections of the interpretation profiles; 7 - intersection points and thicknesses of granitoid beds at the intersections of the interpretation profiles (see Fig. 3 for the positions of the profiles); 8 - root mean square errors (RMSE) for the selection of models on the interpretation profiles.

нального разлома, который одновременно является и северо-восточным ограничением этой котловины. Юго-восточное ограничение котловины, судя по геолого-геофизическим данным, контролируется Гацууртынским региональным разломом (см. рис. 1 и 5), который, продолжаясь далеко на юго-запад, ограничивает Улан-Баторскую (Тольскую) впадину с этого фланга. Таким образом, Сэльбинская котловина расположена в треугольнике, ограниченном Шижирбогдинским, Баянхошуунским и Гацууртынским региональными разломами. Максимальная мощность отложений в этой структуре, по резуль- татам интерпретации геолого-геофизических данных, составляет 400 м и пространственно приурочена к Северо-Тольскому разлому, который пересекает вышеуказанный треугольник в меридиональном направлении. В состав осадочной толщи входят аллювиальные, аллювиально-пролювиальные и верхненеогеновые-плиоценовые отложения (см. рис. 1, 4, 5). В 5 км к юго-западу от Сэльбинской котловины расположен небольшой прогиб фундамента в форме овала с размерами в плане $3 \times 2$ км, длинная ось которого вытянута поперек главных разломных зон и сочленяется с Сэльбинской кот- 


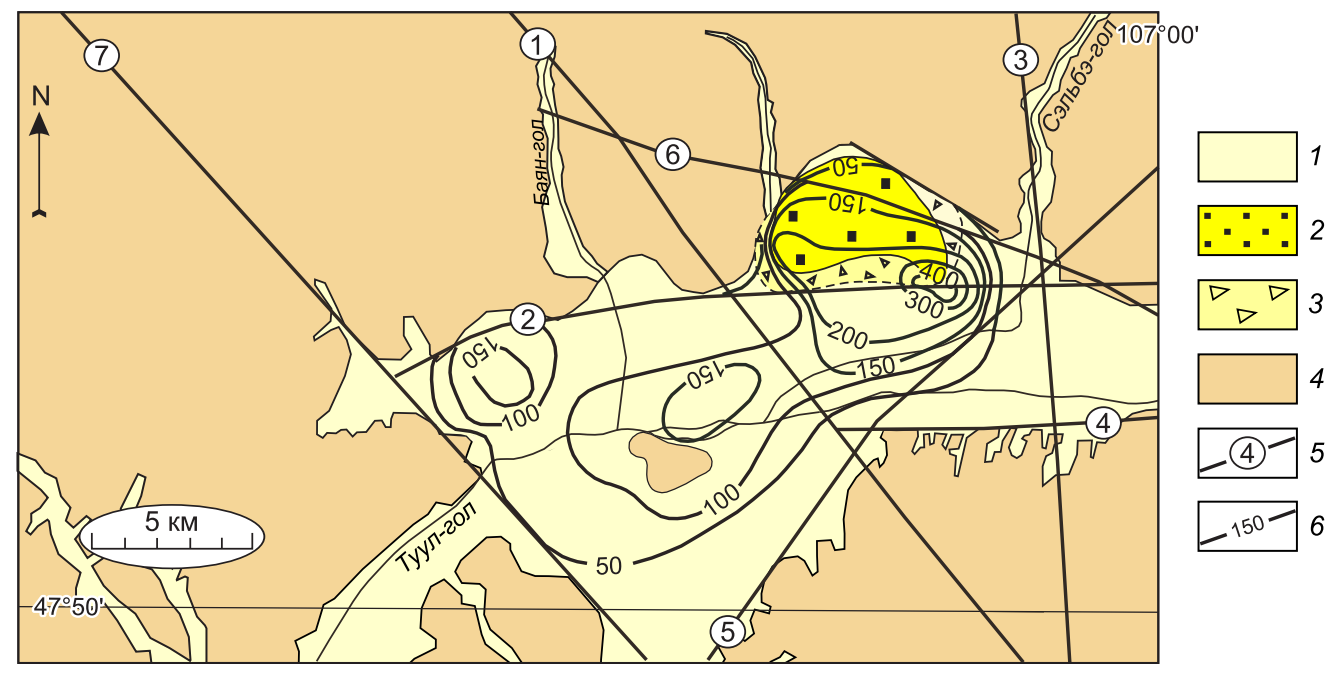

Рис. 5. Схема изопахит осадочных отложений Улан-Баторской (Тольской) впадины. 1-5 - см. усл. на рис. 1; 6 - изопахиты осадочных отложений, м.

Fig. 5. Schematic map of the Ulaanbaatar (Tolskaya) basin showing the isopachites of sediments. 1-5 - see Fig. 1 for the legend; 6 - isopahites of sediments, $\mathrm{m}$.

ловиной в районе Шижирбогдинского разлома. Мощность осадков в нем, судя по результатам интерпретации, достигает 150 м.

К востоку от Сэльбинской котловины (рис. 5), восточнее Сэльбинского разлома (грабена), оценка мощности рыхлых отложений по гравиметрическим данным затруднительна из-за сильного искажающего влияния Богдоулинского мезозойского гранитного массива, создающего, как и осадочные образования, интенсивную отрицательную аномалию силы тяжести. Методами гравиметрии разделить эти эффекты невозможно. Здесь мощность осадочных отложений определена по данным электроразведочных и буровых работ [Bat-Elziy, Dorzh, 1988; Batsayhan, 2006] и составляет не более 30-40 м.

\section{2. НАЛАЙХИНСКАЯ УГЛЕНОСНАЯ ВПАДИНА}

Налайхинская впадина (котловина) мезозойского заложения расположена в пределах Хэнтэйской складчатой области, между горстовыми блоковыми структурами гранитоидов Богдоулинского и Горихинского массивов в 35 км к юго-востоку от УланБаторской (Тольской) депрессии на пересечении Хонхоринской системы грабенов и Дэндэйской системы глубинных разломов, которые контролируют эту структуру (см. рис. 1). Впадина имеет субширотную ориентировку и заполнена нижнемеловыми отложениями Зунбаянской свиты, залегающими с угловым несогласием на терригенных образованиях девона и карбона Хэнтэйской серии. Восточнее Налайхинской впадины расположен целый ряд меж- горных депрессий мезозойского заложения, часть которых угленосные, например Бага-Нурская, с которой связано Бага-Нурское буроугольное месторождение [Dugaraa, Arvysbaatar, 1982].

К Налайхинской депрессии приурочено месторождение бурых углей, поэтому геологическое строение впадины вызывает практический интерес. Для изучения внутренней структуры Налайхинской впадины, оценки мощности заполняющих ее осадочных отложений и определения особенностей морфологии кристаллического фундамента авторами проведена среднемасштабная гравиметрическая съемка, площадь которой превышает 350 км$^{2}$ (см. рис. 2). Работы выполнены с помощью гравиметров scintrex autograv CG-5 по стандартной методике. Среднеквадратическая точность вычисления аномалий $(\varepsilon= \pm 0.015$ мГал) и густота сети наблюдений (всего выставлено 600 координатных пунктов) отвечают техническим требованиям, предъявляемым к гравиметрическим съемкам масштаба 1:100000. Как видно из схемы аномалий силы тяжести в редукции Буге, структура гравитационного поля Налайхинской впадины изометрична. Эпицентр аномалии расположен в 8 км к юговостоку от сомона Налайх, на юго-восточном окончании Хонхоринской системы глубинных разломов. Наиболее интенсивная аномалия силы тяжести расположена в центральной части впадины и может быть связана с линзами отложений мелового и четвертичного возраста.

Средняя разница плотностных характеристик осадочного чехла и фундамента, оцененная по денсиметрическим замерам и по корреляции сейсми- 

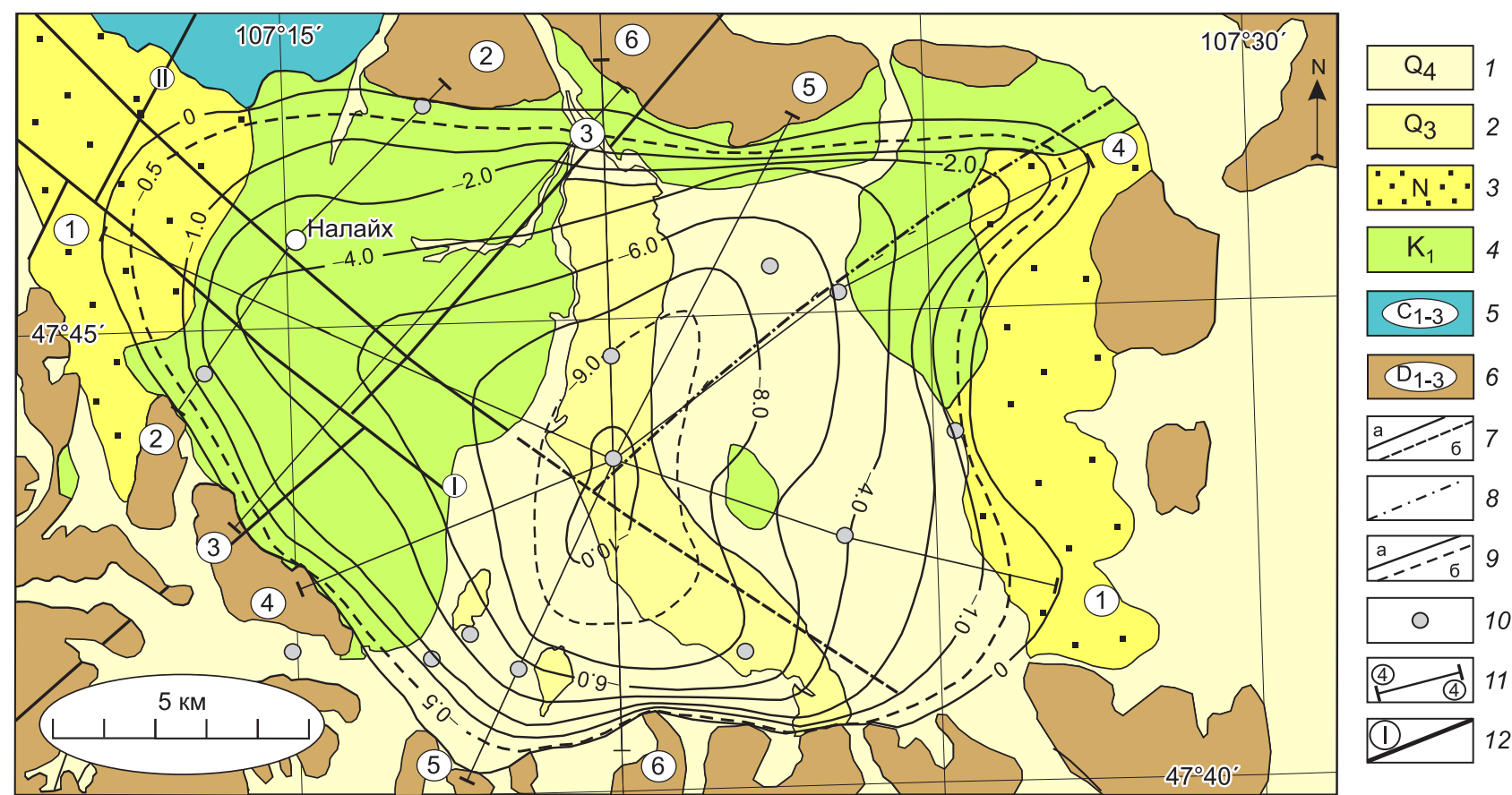

Рис. 6. Схема локальных (остаточных) гравитационных аномалий Налайхинской впадины (в относительном уровне, сечение изоаномал через 1 мГал).

1-7 - см. усл. на рис. 1; 8 - разлом, предполагаемый по гравиметрическим данным; 9 - изоаномалы силы тяжести: а - основные, б - дополнительные; 10 - буровые скважины; 11 - интерпретационные профили. Цифры в кружках (арабские) - номера расчетных профилей; 12 - разломы, установленные по геологическим данным. Цифры в кружках (римские) - их наименования (см. усл. на рис. 1).

Fig. 6. Local (residual) gravity anomalies of the Nalaikha depression (relative level; cross sections of isonomals every $1 \mathrm{mGal})$.

1-7 - see Fig. 1 for the legend; 8 - fault assumed from the gravimetric data; 9 - gravity isoanomals: a - main, 6 - additional; 10 - boreholes/wells; 11 - interpretation profiles (Arabic numbers in circles - profile numbers); 12 - faults confirmed by the geological data (Roman numbers in circles - fault names, see Fig. 1 for the legend).

ческих и гравитационных данных, для Налайхинской впадины составляет -0.35 г/см³ $[$ Turutanov, 2010] и принята авторами настоящей статьи для инверсии поля силы тяжести.

Интенсивность локальных отрицательных аномалий в районе Налайхинской впадины доходит до -11 мГал (рис. 6). Для оценки мощности осадков выполнена количественная интерпретация этих аномалий. Использован метод подбора моделей геологических тел с помощью способа наименьших квадратов. Линза осадков моделировалась ограниченными по простиранию трехмерными призмами с вертикальными сечениями, имеющими форму многоугольников [Godson, 1983; Webring, 1985]. В качестве «нулевого» приближения были использованы результаты решения одномерной обратной задачи гравиметрии для контактной поверхности (в случае плоского слоя).

Результаты инверсии аномалий отражены на интерпретационных разрезах (рис. 7) и составленной на их основе структурной схеме впадины (рис. 8). Эти рисунки дают общее представление о строении впадины и о глубине до кристаллического фундамента. В районах, в которых установлены крутые контакты осадков с вмещающими породами, предполагается наличие разрывных нарушений. В результате гравиметрических исследований получены количественные характеристики мощности осадочных отложений угленосной впадины и сведения о морфологических особенностях погребенной части кристаллического фундамента. Судя по интерпретационным разрезам и схеме мощности осадочных отложений, фундамент Налайхинской впадины имеет сложное блоковое строение (см. рис. 7). Котловина представляет собой почти изометричную структуру, напоминающую равносторонний треугольник, вершины которого слегка вытянуты вдоль установленных по геологическим и предполагаемым по гравиметрическим данным разломам в северо-восточном, северо-западном и юго-восточном направлениях.

На структурной схеме показаны изопахиты отложений в Налайхинской впадине и разломы, выделенные по геологическим данным и частично 

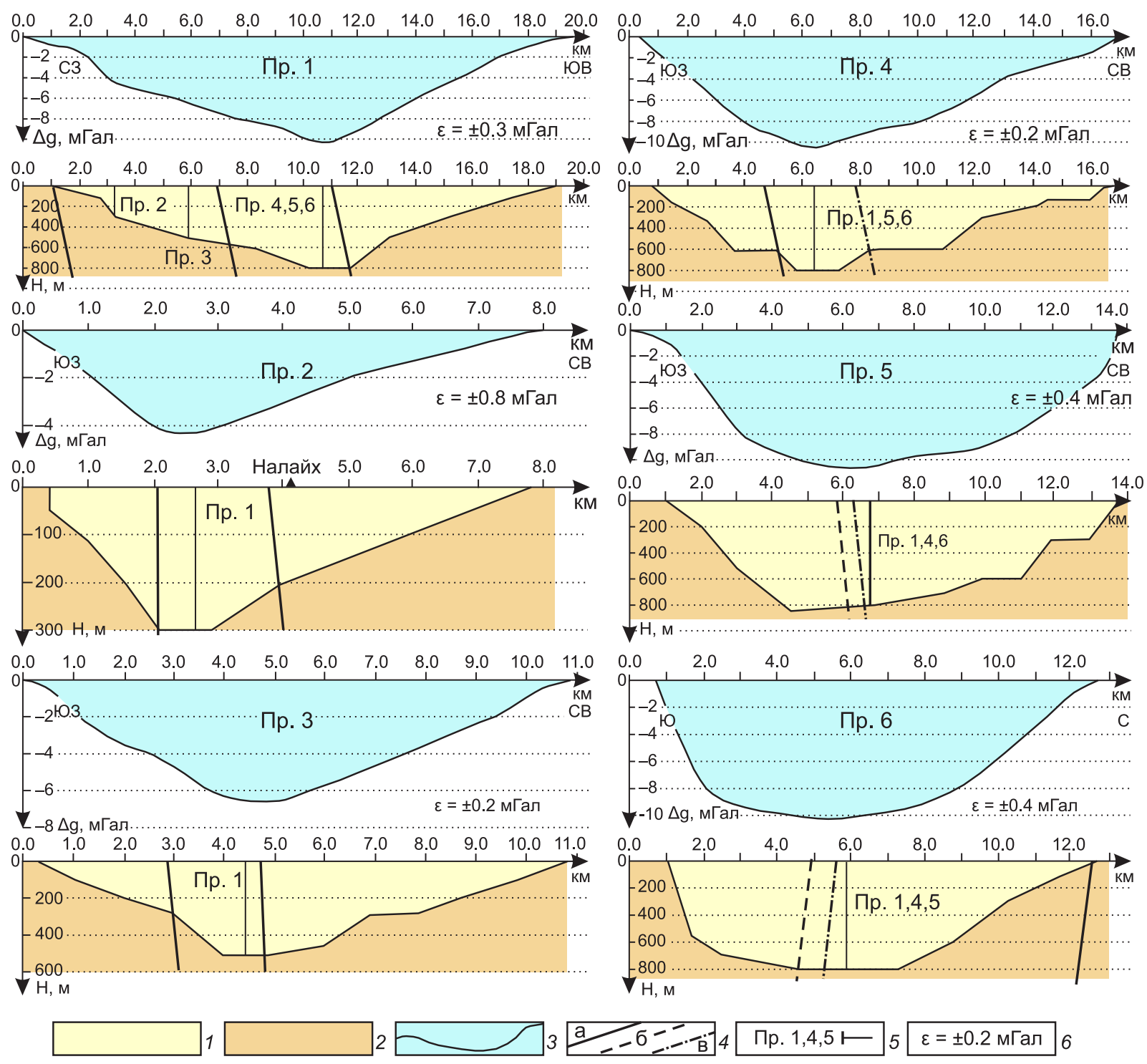

a

Рис. 7. Интерпретационные разрезы Налайхинской впадины.

1 - осадочные отложения; 2 - вмещающие породы; 3 - графики локальных (остаточных) аномалий силы тяжести; 4 - крупные разломы, установленные по геологическим данным (a), предполагаемые по геологическим (б) и геофизическим (в) данным; 5 положение интерпретационных профилей на разрезах и их номера; 6 - среднеквадратические погрешности подбора моделей на интерпретационных профилях.

Fig. 7. Interpretation profiles of the Nalaikha depression.

1 - sediments; 2 - host rocks; 3 - curves of local (residual) gravity anomanlies; 4 - large faults confirmed by the geological data (a), and assumed from the geological (б) and geophysical (в) data; 5 - positions and numbers of the interpretation profiles on the cross sections; 6 - RMSE for the selection of models on the interpretation profiles.

отражающиеся в гравитационном поле. Центральная часть котловины, в которой мощность осадков максимальна и достигает 800 м, расположена к юго-востоку от поселка Налайх и приурочена к Хонхоринскому глубинному разлому (см. рис. 1,8 ).

Южный фланг котловины, судя по морфологии гравитационного поля, ограничен разломом, имеющим субширотную ориентировку. Этот разлом контролирует контакт осадочных отложений четвертичного возраста с коренными породами, пред- ставленными Горихинской свитой нижнего - среднего девона. Северный борт котловины, судя по сгущению изоаномал, также ограничен разломом (скрытым, как и в южном борту, осадочными породами), маркирующим контакт нижне- и среднедевонских пород с меловыми отложениями впадины. В состав осадочной толщи входят аллювиальные, аллювиально-пролювиальные, верхненеогеновые плиоценовые и меловые отложения (см. рис. 1). В 3 км к юго-востоку от центральной части котлови- 

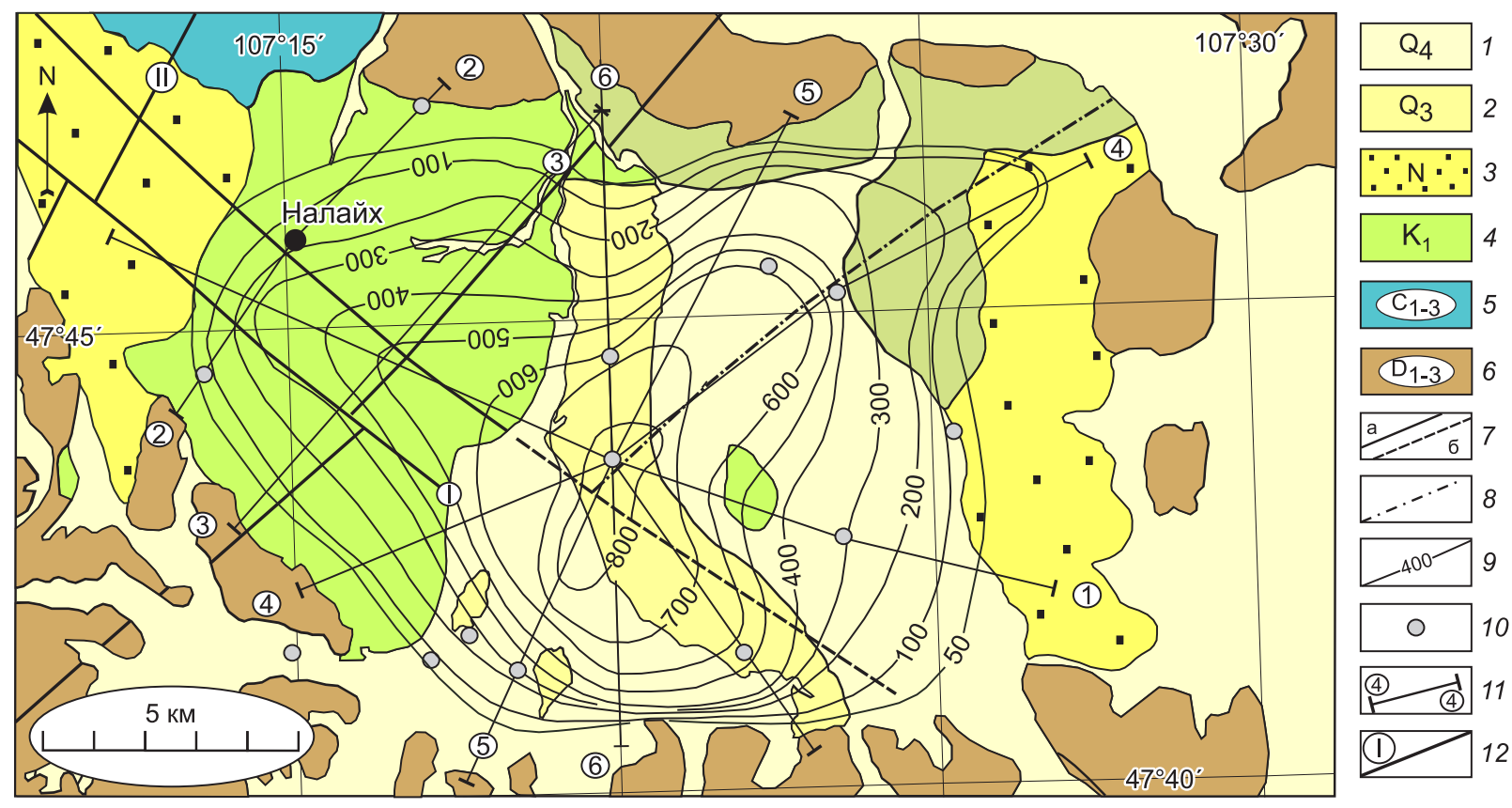

Рис. 8. Схема изопахит осадочных отложений Налайхинской впадины.

1-8 - см. усл. на рис. 1 и 6; 9 - изопахиты осадочных отложений, м; 10 - буровые скважины; 11 - интерпретационные профили. Цифры в кружках (арабские) - номера профилей; 12 - разломы, установленные по геологическим данным. Цифры в кружках (римские) - их наименования (см. усл. на рис. 1).

Fig. 8. Isopachites of the sedimentary deposits of the Nalaikha depression.

1-8 - see Figures 1 and 6 for the legend; 9 - sedimentary isopachites, m; 10 - boreholes/wells; 11 - interpretation profiles (Arabic numbers in circles - profile numbers); 12 - faults confirmed by the geological data (Roman numbers in circles - fault names, see Fig. 1 for the legend).

ны среди пород четвертичного возраста картируется небольшой $(2 \times 1$ км) останец нижнемеловых пород, маркирующий, судя по гравитационному полю, их малую мощность. В районе сомона Налайх, где расположено промышленное месторождение бурых углей, мощность осадочных отложений котловины составляет 200 м (см. рис. 7 и 8 , профиль 2).

\section{3. БоГДОУЛИНСКИЙ ГРАНИТНЫЙ МАССИВ}

Для изучения глубинного строения Богдоулин-

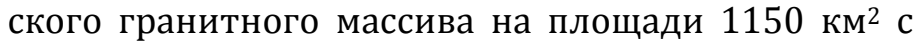
помощью гравиметра CG-5 выставлено 178 координатных пунктов наблюдения. Точность наблюдений составила \pm 0.02 мГал. Высота пунктов определялась приборами Trimble 5700 GPS, точность измерений составила \pm 0.35 м. Над этим гранитным массивом наблюдается наиболее интенсивное понижение гравитационного поля, наблюдаемое в районе исследований. Эпицентр аномалии практически полностью совпадает с выходами гранитоидов (см. рис. 2). Аномалия осложнена минимумами более высокого порядка, которые приурочены непосредственно к выходам гранитов на земную поверхность. Судя по морфологии гравитационно- го поля, можно полагать, что изменение мощности Богдоулинского массива происходит главным образом за счет неровностей подошвы плутона. Схема локальных (остаточных) аномалий силы тяжести в районе Богдоулинского массива построена по четырем профилям (рис. 9). Линии профилей, на которых изменение регионального поля предполагалось линейным, были ориентированы преимущественно поперек вытянутости массива. Интенсивность локальных отрицательных аномалий в районе Богдоулинского массива доходит до 18-20 мГал. Результаты интерпретации гравитационных аномалий вдоль профилей отражены на интерпретационных разрезах (рис. 10) и составленной на их основе схеме мощности гранитоидов Богдоулинского массива (рис. 11).

Богдоулинский гранитный плутон выделяется в виде изометричного массивного крупного тела. Судя по интерпретационным разрезам и схеме мощности (см. рис. 10 и 11), построенной по результатам трехмерного подбора моделей, Богдоулинский массив имеет сложное «клавишное» строение и представлен клиновидными блоками, конфигурация и особенности формы которых совпадают с направлением крупных разрывных нарушений, 


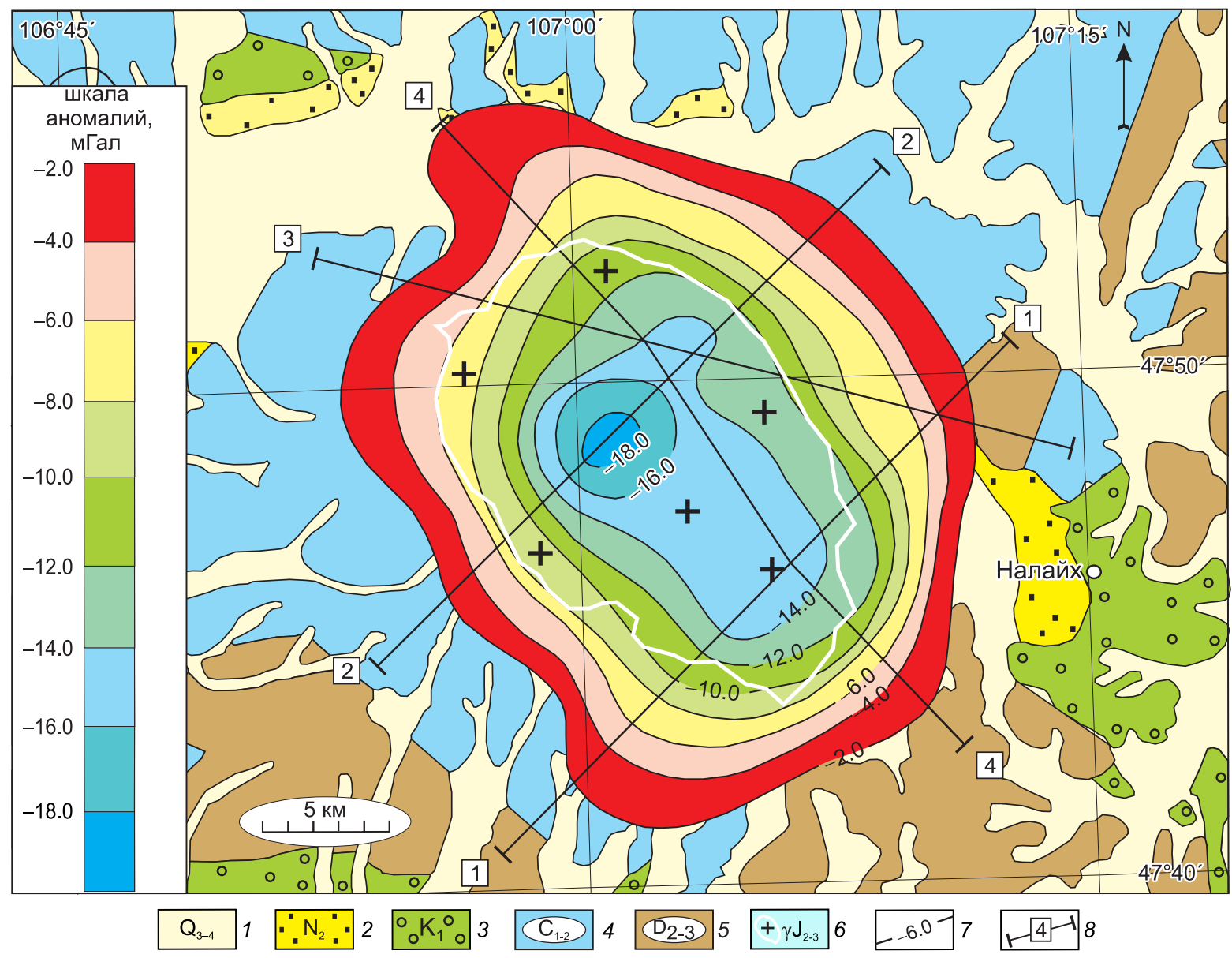

Рис. 9. Схема локальных (остаточных) гравитационных аномалий Богдоулинского гранитного массива (в относительном уровне, сечение изоаномал через 2 мГал). 1-6 - см. усл. на рис. 1; 7 - изоаномалы силы тяжести, мГал; 8 - интерпретационные профили. Цифры в квадратах - номера профилей.

Fig. 9. Local (residual) gravity anomalies of the Bogdoulin granitic massif (relative level; cross sections of isoanomals every 2 mGal). 1-6 - see Fig. 1 for the legend; 7 - gravity isoanomals, mGal; 8 - interpretation profiles (numbers in squares profile numbers).

ограничивающих массив (см. рис. 1). Плутон имеет форму овала с размерами $30 \times(15-20)$ км, его длинная ось направлена на северо-запад и совпадает с направлением Шижирбогдоулинского, Сэльбинского, Баянхошуунского, Сонгиноульского и Хонхорынского глубинных разломов, которые ограничивают Богдоулинский массив с юго-запада и северовостока (см. рис. 1).

Северное ограничение массива контролируется Южно-Тольской системой крупных тектонических нарушений, южное - Дэндэйской системой глубинных разломов (см. рис. 1, 11). Южная часть массива пересечена региональным Хундайским разломом, параллельным Дэндэйской системе и расположенным в 10-12 км севернее ее. Максимальная мощность гранитоидов, судя по результатам интерпретации гравиметрических данных, составляет 9.0 км (см. рис. 10, профиль 2). Северо-северо-западная часть интрузии ограничена Тольской системой глубинных разломов с севера, Сэльбинским разломом с запада и Баянхошуунским разломом с востока (см. рис. 1, 11). В пределах площади, ограниченной этими структурами, толщина гранитоидов изменяется от 1 до 2 км (см. рис. 10, профиль 4). Юговосточное ограничение плутона фиксируется Дэндэйской системой глубинных разломов, имеющей северо-восточную ориентировку (см. рис. 1, 11). Толщина гранитоидов в этой части плутона составляет около 1 км.

Северо-восточное ограничение Богдоулинского массива находится восточнее Хонхоринского разлома, имеющего северо-западную ориентировку. Толщина плутона в этом районе составляет 0.51.5 км. Юго-западная граница плутона расположена в 4 км к западу от Шижирбогдоулинского разлома (см. рис. 1 и рис. 10, профили 1-3). Толщина массива здесь составляет 0.5-3.0 км. Максимальное значение мощности гранитоидов массива отмечается 

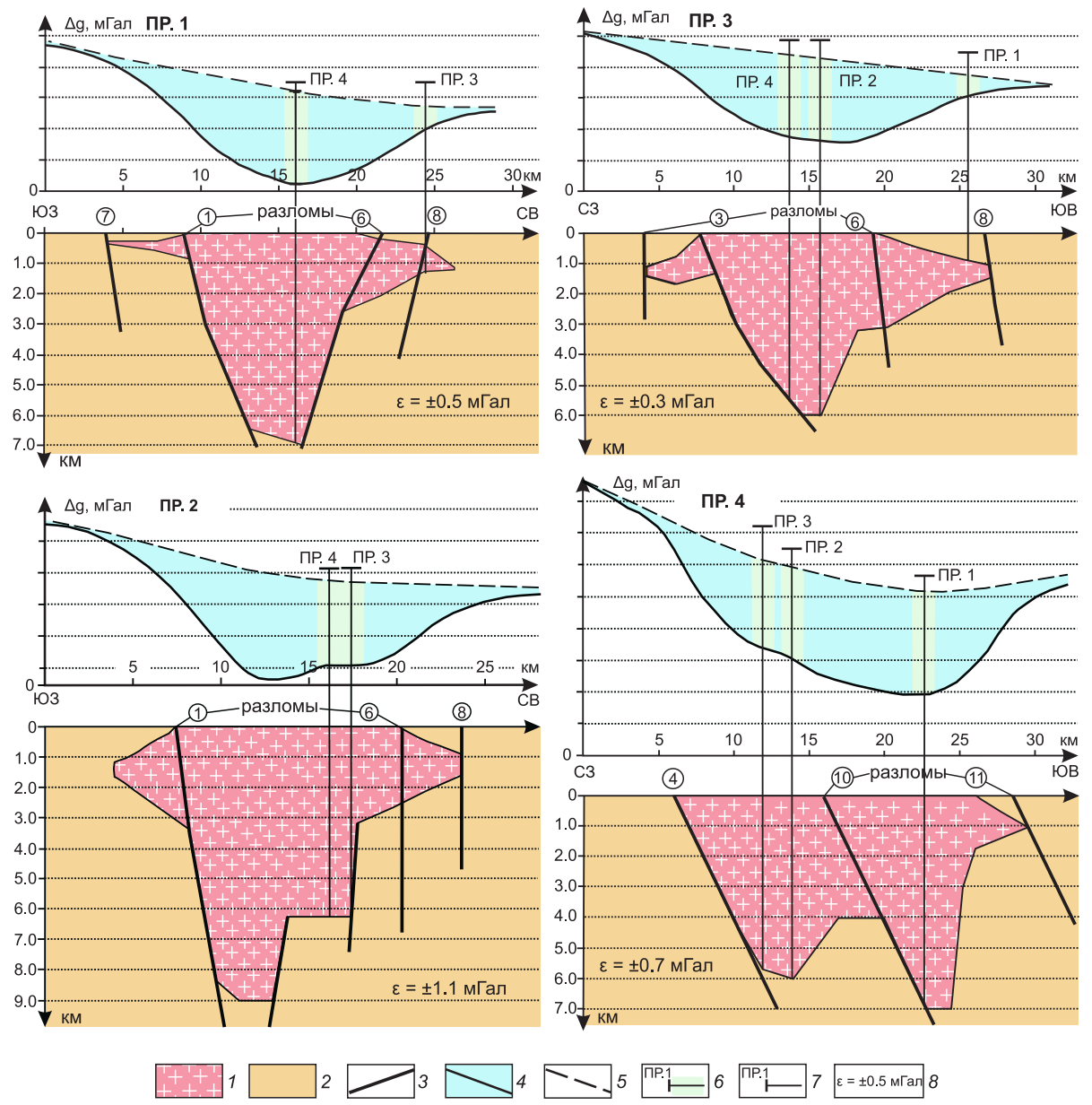

Рис. 10. Интерпретационные разрезы Богдоулинского гранитного массива.

1 - гранитоиды массива; 2 - вмещающие породы; 3 - крупные разломы, установленные по геологическим данным. Цифры в кружках - номера и названия разломов (см. усл. на рис. 1); 4 - графики аномалий силы тяжести в редукции Буге; 5 - графики регионального фона; 6 - точки пересечения и значения величины регионального фона в местах пересечения интерпретационных профилей; 7 - точки пересечения и значения мощности (толщины) гранитоидов в местах пересечения интерпретационных профилей; 8 - среднеквадратические погрешности подбора моделей на интерпретационных профилях.

Fig. 10. Interpretation profiles of the Bogdoulin granite massif.

1 - granitoids; 2 - host rocks; 3 - large faults confirmed by the geological data. Numbers in circles - fault numbers and names (see Fig. 1 for the legend); 4 - curves of Bouguer gravity anomalies; 5 - regional background gravity curves; 6 - intersection points and values of the regional background gravity at the intersections of the interpretation profiles; 7 - intersection points and thicknesses of granitoids at the intersections of the interpretatiion profiles; 8 - standard errors of selection of models on the interpretation profiles.

в районе профиля 2 (см. рис. 10) и составляет 9.0 км. Как и ожидалось при описании гравитационного поля, изменение мощности плутона, судя по результатам интерпретации, происходит за счет неровностей подошвы (см. рис. 10, профили 1-3).

Определение возраста гранитов Богдоулинского массива по цирконам, выполненное уран-свинцовым методом в лаборатории изотопов Института минералогии в Университете г. Фрайберга (ФРГ), дали величину, лежащую в пределах $(205 \pm 4.1) \div$ (208.4ะ9.1) млн лет, то есть датировали становление гранитоидов ранним мезозоем [Khishigsuren, 2006]. Минералогические исследования Богдоулинского массива показали, что повышенные содержания редкометалльных минералов связаны со второй фазой гранитоидов, представленной лейкогранитами и гранитами, и концентрируются на северо-восточной окраине плутона, что совпадает с геохимическими данными, полученными ранее [Khishigsuren, 2006], которые свидетельствуют, что в гранитоидах массива присутствует аномально высокое содержание $\mathrm{Sn}$ (до 25 мг/кг), Zn (до 81 мг/ кг) и W (до 11 мг/кг). Кроме того, на многих участках массива обнаружена точечная концентрация молибденита и касситерита.

Необходимо отметить, что, интерпретируя гравитационные аномалии, мы в большинстве случаев получаем довольно грубое представление о глу- 


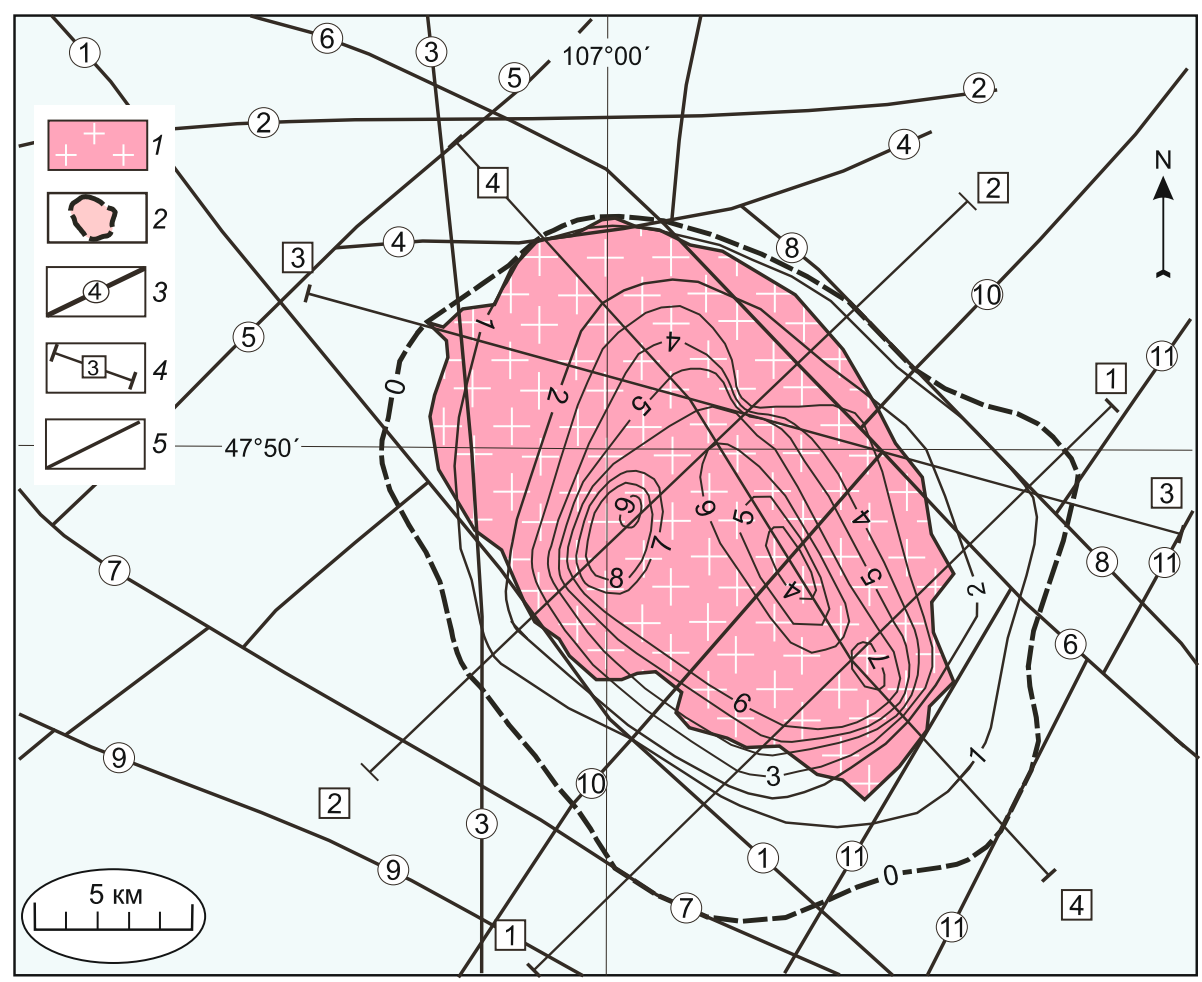

Рис. 11. Схема мощности (толщины) Богдоулинского гранитного массива.

1 - гранитоиды массива; 2 - площадь проекции массива на земную поверхность; 3 - крупные разломы, установленные по геологическим данным. Цифры в кружках - номера и наименования разломов (см. усл. на рис. 1); 4 - интерпретационные профили. Цифры в квадратах - номера профилей; 5 - изолинии мощности (толщины) гранитоидов, км.

Fig. 11. Diagram of the Bogdoulin granite massif thickness.

1 - granitoids; 2 - projection area of the massif to ground surface; 3 - large faults confirmed by the geological data (numbers in circles fault numbers and names, see the Fig. 1 for the legend); 4 - interpretation profiles (numbers in squares - profile number); 5 - isolines of granitoid thickness, $\mathrm{km}$.

бинной структуре гранитных плутонов, даже при известном недостатке плотности и учете положения их выходов на земную поверхность. Составленная нами схема строения толщины плутона дает лишь общее представление о глубинной структуре интрузии. В ряде случаев на ней, видимо, сильно искажены глубины и пропущены боковые апофизы, вытянутые в горизонтальном направлении.

\section{5. ЗАКЛЮЧЕНИЕ}

На территории Улан-Баторского района (Центральная Монголия) авторами выполнена площадная среднемасштабная гравиметрическая съемка. Форма и размеры геологических тел определены с помощью полуавтоматизированного 3D-метода подбора. По результатам интерпретации гравитационных аномалий построена схема глубинного строения района (рис. 12).

Улан-Баторская (Тольская) впадина разделяется на две котловины: западную и восточную (см. рис.
$5,12)$. В западной котловине мощность кайнозойских отложений составляет около 150 м, в восточной котловине она может достигать 400 м. Относительно молодой возраст Тольской впадины позволяет предполагать, что сейсмический потенциал этого района может быть достаточно высоким, поэтому сведения о мощности осадков и морфологии фундамента, вместе со сведениями о разломах, чрезвычайно важны и могут быть использованы при инженерно-сейсмологических работах по уточнению сейсмической опасности как отдельных участков впадины, так и г. Улан-Батора. Рядом с городом расположена Сэльбинская котловина, в которой толщина линзы осадков максимальна. Поскольку Южно-Тольский и Сэльбинский региональные разломы (см. рис. 1 и 12), судя по геологогеофизическим данным, контролируют положение субширотной тектонической структуры Тольской впадины, ее развитие связано с указанными разломами, которым свойственна и современная сейсмотектоническая активность. В связи с этим район пересечения Сэльбинской и Тольской систем раз- 

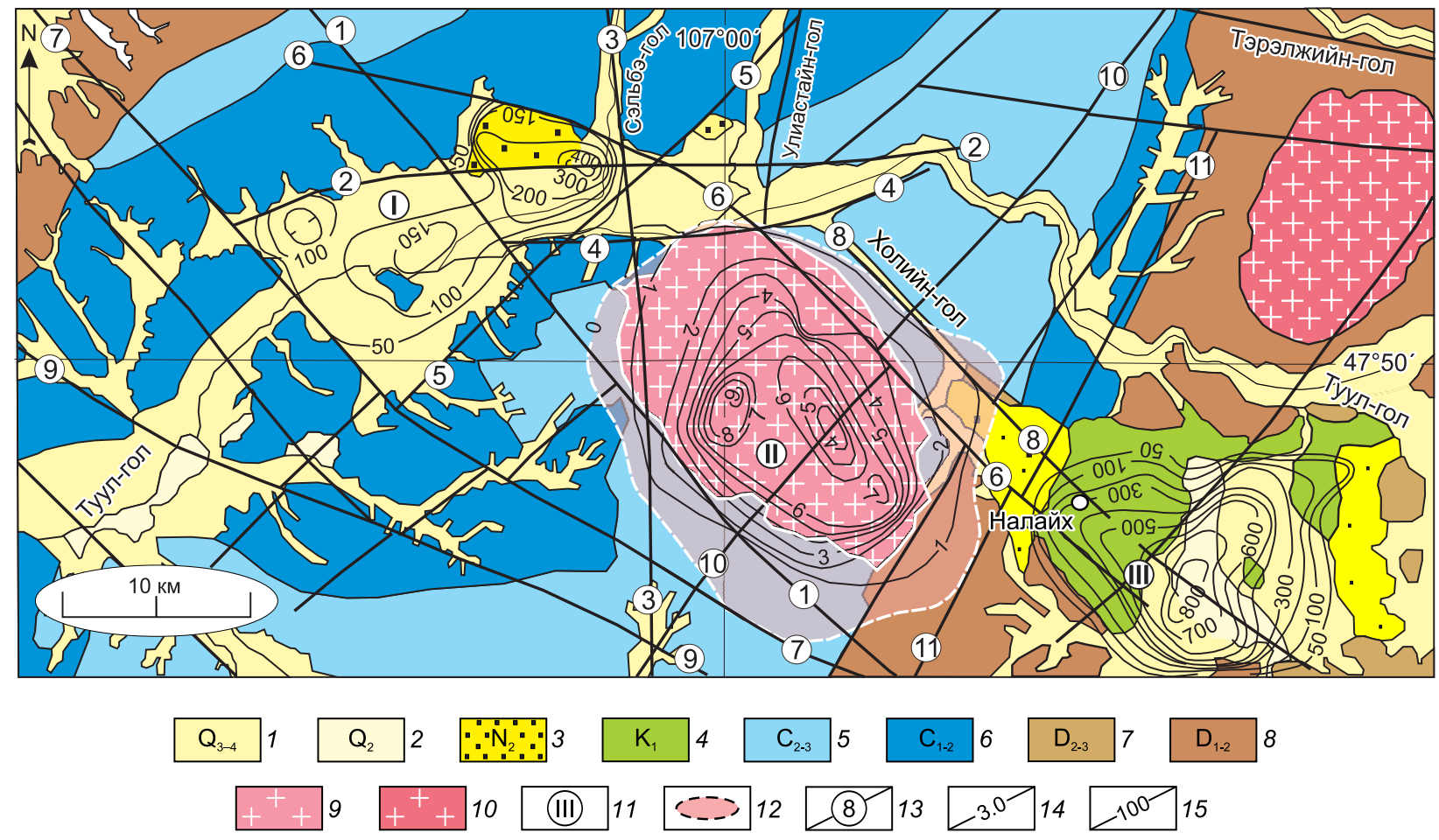

Рис. 12. Геолого-геофизическая схема глубинного строения Улан-Баторского района. Условные обозначения 1-11 см. на рис. $1 ; 12$ - площадь проекции Богдоулинского гранитного массива на земную поверхность; 13 - крупные разломы (см. на рис. 1); 14 - изолинии мощности (толщины) гранитоидов, км; 15 - изопахиты осадочных отложений, м.

Fig. 12. Geological-geophysical scheme of the deep structure of the Ulaanbaatar region. 1-11 - see Fig. 1 for the legend; 12 projection area of the Bogdoulin granite massif on the ground surface; 13 - large faults (see Fig. 1); 14 - isolines of granitoid thickness, $\mathrm{km}$; 15 - isopachites of sediments, $\mathrm{m}$.

ломов, к которому приурочена, судя по гравиметрическим данным, максимальная мощность осадочных отложений Улан-Баторской впадины (Сэльбинская котловина), может оказаться крупной сейсмогенерирующей структурой.

B результате 3D гравитационного моделирования установлено, что фундамент Налайхинской угленосной депрессии имеет блоковое строение и расчленен разломами северо-восточного и северозападного направления. Максимальная мощность осадочных отложений в котловине составляет 800 м и приурочена к региональному глубинному разлому. Подобное строение характерно для ряда впадин, расположенных восточнее Налайхинской депрессии, для которых комплексом геофизических методов установлены аналогичные мульдообразные прогибы фундамента и к которым приурочены месторождения бурого угля. Сведения о мощности осадков и морфологии фундамента могут быть использованы для уточнения перспектив эксплуатации Налайхинского угольного месторождения и проведения общих поисковых работ с применением колонкового бурения.

Анализ результатов инверсии поля силы тяжести позволил определить форму и размеры Бог- доулинского гранитного массива, расположенного вблизи г. Улан-Батора. Максимальная толщина тела составляет 9.0 км, площадь проекции на земную поверхность - около 350 км² $^{2}$ (при площади выходов, составляющей около 250 км$^{2}$ ). Гравиметрические данные подтвердили блоковое строение массива, границы которого контролируются крупными разломами, установленными по геологическим данным. Знание морфологии подземной части Богдоулинского плутона может быть полезно при оценке его перспектив на обнаружение редких и цветных металлов, аномально высокое содержание которых (Sn, Zn, W), а также высокая концентрация молибденита и касситерита связаны с особенностями его формы и установлены геологогеофизическими и геохимическими исследованиями.

Можно полагать, что хотя гравиметрия дает сравнительно небольшое количество достоверных сведений о форме и размерах крупных плотностных неоднородностей верхней части земной коры, эта информация достаточно важна для геологов и пока не может быть получена никакими другими методами с равными затратами средств. 


\section{6. ЛИТЕРАTУРА / REFERENCES}

Bat B., 2004. Assesment and Prediction of Stability of the Geological Medium to Natural and Technogenic Impacts of the Territory of the City of Ulaanbaatar. PhD Thesis Summary (Candidate of Geology and Mineralogy). Irkutsk, 30 p. (in Russian) [Бат Б. Оценка и прогнозирование устойчивости геологической среды к природным и техногенным воздействиям территории города Улаанбаатар: Автореф. дис. ... канд. геол.-мин. наук. Иркутск, 2004. 30 с.].

Bat-Elziy Sh., Dorzh D., 1988. Report on Hydrogeological and Geophysical Studies of 1982-1986. Water Research Institute of Mongolia, Ulaanbaatar, 232 p (in Russian) [Бат-Элзий Ш., Дорж Д. Отчет о гидрогеологических и геофизических работах, проведенных в 1982-1986 гг. Улаанбаатар: Фонды ПИнИИ водного хозяйства МНР, 1988. 232 c.].

Batsayhan Ts., 2006. Geophysical Engineering Assessment of Seismic Hazard of Soils in the Territory of the City of Ulaanbaatar. PhD Thesis Summary (Candidate of Geology and Mineralogy). Irkutsk, 19 p. (in Russian) [Батсайхан Ц. Инженерно-геофизическая оценка сейсмической опасности грунтов территории г. Улаанбаатара: Автореф. дис. ... канд. геол.-мин. наук. Иркутск, 2006. 19 с.].

Didenko A.N., Mossakovskii A.A., Pecherskii D.M., Ruzhentsev S.V., Samygin S.G., Kheraskova T.N., 1994. Geodynamics of the Central-Asian Paleozoic oceans. Geologiya i Geofizika (Russian Geology and Geophysics) 35 (7-8), $59-75$ (in Russian) [Диденко А.Н., Моссаковский А.А., Печерский Д.М., Руженцев С.В., Самыгин С.М., Хераскова Т.Н. Геодинамика палеозойских океанов Центральной Азии // Геология и геофизика. 1994. Т. 35. № 7-8. С. 59-75].

Dugaraa P., Arvysbaatar N., 1982. Geologics features of the Burulzhutin and Nalaiha depressions of Central Mongolia. In: Problems of geology and mineral resources of Central and Eastern Mongolia. Ulaanbaatar, p. 13 (in Russian) [Дугараа П., Арвисбаатар Н. Геолого-структурные особенности Бурульжутинской и Налайхинской впадин Центральной Монголии // Вопросы геологии и полезных ископаемых Центральной и Восточной Монголии. Улаанбаатар, 1982. С. 13].

Dzhurik V.I., Klyuchevsky A.V., Serebrennikov S.P., Dem'yanovich V.M., Batsayhan Ts., Bayaraa G., 2009. Seismicity and Seismic Hazard Zoning of the Territory of Mongolia. IEC SB RAS, Irkutsk, 420 p. (in Russian) [Джурик В.И., Ключевский А.В., Серебренников С.П., Демьянович В.М., Батсайхан Ц., Баяраа Г. Сейсмичность и районирование сейсмической опасности территории Монголии. Иркутск: ИЗК СО РАН, 2009. 420 с.].

Godson R.H., 1983. GRAVPOLY: a Modification of Three-Dimensional Gravity Modeling Program. USGS Open File Report 83-346. U.S. Geological Survey, Denver, 53 p. https://doi.org/10.3133/ofr83346.

Khishigsuren S., 2006. Bogd Uul granite pluton and related mineralization, Central Mongolia. In: Mineral resources of Mongolia in the 21st Century. Abstracts of the conference dedicated to the 75th anniversary of the signing of the treaty between Mongolia and Russia on cooperation in the field of geology. Ulaanbaatar, p. 108-109.

Marinov O.N., Zonenshain L.P., Blagonravov V.A. (Eds.), 1973. Geology of the Mongolian People's Republic. Vol. 1. Stratigraphy. Nedra, Moscow, 582 p. (in Russian) [Геология Монгольской Народной Республики. Том 1. Стратиграфия / Ред. Н.А. Маринов, Л.П. Зоненшайн, В.А. Благонравов. М.: Недра, 1973. 582 с.].

Medvedev S.V. (Ed.), 1971. Seismic Zoning of Ulaanbaatar. Nauka, Moscow, 206 p. (in Russian) [Сейсмическое районирование Улан-Батора / Ред. С.В. Медведев. М.: Наука, 1971. 206 с.].

Nagibina M.S., 1963. Tectonics and Magmatism of the Mongolia-Okhotsk Belt. Publishing House of the USSR Acad. Sci., Moscow, 463 p. (in Russian) [Нагибина М.C. Тектоника и магматизм Монголо-Охотского пояса. М.: Изд-во АН CCCP, 1963. 463 c.].

Turutanov E.Kh., 2010. Structure of the Cenozoic Depressions of the Northeastern and Southwestern Terminations of the Baikal Rift System According to Gravimetric Data. ISTU Publishing House, Irkutsk, 167 p. (in Russian) [Typyтанов E.X. Строение кайнозойских впадин северо-восточного и юго-западного окончаний Байкальской рифтовой системы по гравиметрическим данным. Иркутск: Изд-во ИрГТУ, 2010. 167 с.].

Turutanov E.Kh., 2011. Morphology of Basic Intrusions of the Olkhon Region According to Gravimagnetic Data (Western Pribaikalie). ISTU Publishing House, Irkutsk, 208 p. (in Russian) [Турутанов Е.Х. Морфология базитовых интрузий Ольхонского региона по гравимагнитным данным (Западное Прибайкалье). Иркутск: Изд-во ИрГТУ, 2011. 208 с.].

Turutanov E.Kh., 2012a. Composition and morphology of large density inhomogeneities of the crust - a factor of influence on seismic activity. Otechestvennaya Geologia (Russian Geology) (3), 66-72 (in Russian) [Турутанов E.X. Состав и морфология крупных плотностных неоднородностей земной коры - фактор влияния на сейсмическую активность // Отечественная геология. 2012. № 3. С. 66-72].

Turutanov E.Kh., 2012b. Morphology of Mongolian Mesozoic Granite Plutons According to Gravimetric Data. ISTU Publishing House, Irkutsk, 223 p. (in Russian) [Турутанов E.X. Морфология мезозойских гранитных плутонов Монголии по гравиметрическим данным. Иркутск: Изд-во ИрГТУ, 2012. 223 с.].

Vakhromeev G.S., 1979. On the formation of physical and geological models of mineral deposits of the Mongolian People's Republic. In: Problems of geology and metallogeny of Eastern Mongolia. Publishing House of the Mongolian State University, Ulaanbaatar, p. 236-244 (in Russian) [Вахромеев Г.С. К вопросу формирования физикогеологических моделей месторождений полезных ископаемых МНР // Вопросы геологии и металлогении Восточной Монголии. Улаанбаатар: Изд-во МонГУ, 1979. С. 236-244].

Webring M., 1985. SAKI: a Fortran Program for Generalized Linear Inversion of Gravity and Magnetic Profiles. USGS Open-File Report 85-122. U.S. Geological Survey, Denver, 110 p. https://doi.org/10.3133/ofr85122. 
B. Buyantogtoh et al.: Crustal structure of the Ulaanbaatar region, Mongolia...

Yanshin A.L. (Ed.), 1975. Mesozoic and Cenozoic Tectonics and Magmatism of Mongolia. Nauka, Moscow, 308 p. (in Russian) [Мезозойская и кайнозойская тектоника и магматизм Монголии / Ред. А.Л. Яншин. М.: Наука, 1975. 308 c.].

Zorin Y.A., Kozhevnikov V.M., Novoselova M.R., Turutanov E.K., 1989. Thickness of the lithosphere beneath the Baikal rift zone and adjacent regions. Tectonophysics 168 (4), 327-337. https://doi.org/10.1016/0040-1951(89)90226-6.

Zorin Yu.A., Belichenko V.G., Turutanov E.Kh., Mordvinova V.V., Kozhevnikov V.M., Khosbayar P., Tomurtogoo O., Arvisbaatar N., Gao S., Davis P., 1994. Baikal-Mongolia transect. Geologiya i Geofizika (Russian Geology and Geophysics) 35 (7-8), 94-110 (in Russian) [Зорин Ю.А., Беличенко В.Г., Турутанов Е.Х., Мордвинова В.В., Кожевников В.М., Хозбаяр П., Томуртогоо О., Арвисбаатар Н., Гао Ш., Дэвис П. Байкало-Монгольский трансект // Геология и геофизика. 1994. Т. 35. № 7-8. С. 94-110].

\section{CВEДЕНИЯ ОБ АВTOPAX | INFORMATION ABOUT AUTHORS}

\section{Базарин Буянтогтох}

H.C.

Институт астрономии и геофизики МАН

13343, Улан-Батор, ул. Ж. Лхагаасурэнгийн, 42, Монголия

e-mail: bazaryn_b@yahoo.com

\section{Евгений Хрисанфович Турутанов}

докт. геол.-мин. наук, зав. лабораторией

Институт земной коры СО РАН

664033, Иркутск, ул. Лермонтова, 128, Россия

凶e-mail: tur@crust.irk.ru

\author{
Виктор Степанович Канайкин \\ канд. геол.-мин. наук, доцент \\ Иркутский национальный исследовательский \\ технический университет \\ 664074, Иркутск, ул. Лермонтова, 83, Россия \\ e-mail: kanvs@yandex.ru
}

\section{Bazarin Buyantogtokh}

Researcher

Institute of Astronomy and Geophysics of MAS

42 J. Lhagaasurengiin street, Ulaanbaatar 13343, Mongolia

\section{Evgenii Kh. Turutanov}

Doctor of Geology and Mineralogy, Head of Laboratory

Institute of the Earth's Crust, Siberian Branch of RAS

128 Lermontov street, Irkutsk 664033, Russia

\section{Victor S. Kanaikin}

Candidate of Geology and Mineralogy, Assistant Professor

Irkutsk National Research Technical University

83 Lermontov street, Irkutsk 664074, Russia 